\title{
Remixing the Dance Education Classroom
}

\author{
Susan R. Koff \\ NYU Steinhardt, USA
}

Dance Education and Music Education are not the same, but are often considered together as Arts Education along with Theatre Education and Art Education. The history of Dance Education as a discipline is much shorter than Music Education, so Dance Education often looks to music education for leadership as well as scholarship. Remixing the Classroom has taken the lead in defining a long-standing issue within Music Education. This essay provides a brief background of Dance Education so as to consider the same Open Philosophy of Music Education, covered in this book, within the discipline of Dance Education.

Keywords: Dance Education, dance education history, arts education pedagogy

I

enter this discussion as a dance educator, not a music educator. Yet so many of the themes of Remixing the Classroom resonate within dance education. There are many points in the text that I could actually read replacing "music education" with "dance education" and it is something I would like to include in readings for my students, who are graduate students in dance education. However, dance education and music education are not synonymous terms and there are inherent concepts of dance education that I must first explore to completely analyze Remixing the Classroom. What is dance education and does dance education have an intersection or inside comprehension into music education? Dance entered public schools as well as universities much later chronologically than music, so, not only is the history shorter, but this history was supported by the strength of music within these educational settings. This discussion begins with a brief history of dance education.

(C) Susan R. Koff. 2017. The content of this article is the sole responsibility of the author. The ACT Journal and the Mayday Group are not liable for any legal actions that may arise involving the article's content, including, but not limited to, copyright infringement. 
Dance entered higher education as just a single academic focus: dance, rather than as dance performance, dance history, or dance education. Beginning with the program in the University of Wisconsin in 1926, dance began as a degree area through physical education. It was started by Margaret H'Doubler, who originally was a women's basketball coach. Dance was a good match with physical education at Wisconsin because H'Doubler's idea was to develop a "sound and scientifically based approach to learning in human movement" (Hagood 2000, 91). Not many years later (1930) Martha Hill became an instructor of dance in the Physical Education Department at New York University (NYU) but the "major overriding concept that Hill would bring to NYU was the idea of dance as a performing art" (McPherson 2008, 28). This began the tension between dance as art or dance as sport in higher education. Dance that originally entered higher education through physical education across the country has been separating from physical education ever since, depending on the structure of each individual university. In many instances, the separation of dance from physical education within higher education was through an alignment of dance with already established music departments or colleges. For example, Martha Hill was able to accomplish her desires of bringing the performing art focus of dance to higher education through the establishment of the Dance Department at Julliard in 1951. This was the beginning of the conservatory focus of dance in higher education, further placing stress on dance as a discipline within higher education (as to where it is aligned), as well as the definition of dance education. The master/apprentice model that Allsup (2016) discusses also entered the university in dance through this conservatory focus. Hagood (2000) refers to the conflict within foci in dance as the "ensuing conflict between liberal and professional orientations" and felt that this was developed mostly through the 1960s (288). In this implication, liberal means a discipline that is open for study by all who are interested (as in a liberal arts education); and professional orientations are those who are gifted and talented, directed toward a performance career. This professional orientation, as the conservatory model began, entails being trained by those who have had a successful career, in hopes of this success being passed on to the students; in other words, a master working with apprentices who hope to gain mastery through this study.

Dance education during this period after the conservatory focus took hold, narrowly defined as teacher education and certification, developed into a second tier 
within higher education, as dancing took priority. "Those who do, dance. Those who can't, teach" became the adage through this split that Hagood (2000) described. This adage is in existence in many disciplines and seems to cast a pall over the conscious choice to enter formal teacher education, as if it is the backup plan. Discussions about the place of dance in higher education frequently surround the source of this division. One possible theory is that, as dance began in higher education its affiliation was the field of physical education which performing artists dismiss (Hagood 2000). When creating the conservatory model, as Hill did, this possibly relegated the teaching model to the sidelines, as an education focus does not exist in the conservatory. Also during the same period, active dance performers could find employment stability within higher education. This confused the nature of qualifications for academic positions. Within non-arts disciplines, the highest academic degree conferred became the criteria for academic employment. However, in dance, the highest accolades conferred became the criteria for academic employment. When higher education faculty in dance included both those who entered through physical education mingled with those who entered through the professional performance world, a clear hierarchy was created, making a focus on education second tier. Job descriptions today for dance positions within higher education still allow for expertise as a performer and/or choreographer to be a substitute qualification (for an earned degree) for those who are heavily recruited in dance departments in colleges and universities.

The term dance education, over the period that dance has been in academia, has been misused, misunderstood, and relegated to the sidelines as dance has flourished in higher education. Remixing the Classroom, while not focusing on dance education, certainly implies the same occurs with music education. When dance education is discussed in contrast to all the other branches of dance in academia, it most often refers to training, and not the full definition that I have promoted (Koff 2000), which is a holistic education, much beyond training. Unlike music, dance entered academia first as dance education (Wisconsin in 1926), in the holistic definition but was named only dance, rather than dance education. However, over very different histories, music education and dance education have arrived at the same point when it concerns holistic education versus training for performance. 
The conservatory model is clear that its focus is directed toward a performance career for the graduates. Martha Hill began the first conservatory in dance at Julliard, which already had conservatory training in music (McPherson 2008). The clear goal of a conservatory degree in dance is that the graduates become performers in well-known professional dance companies. Entrance into a conservatory program is by audition which clearly resembles the audition that is given for openings in a professional dance company. The audition begins with a technique class that represents the overall style of the program (or company) and it moves into excerpts from repertory. People within the group are eliminated at various moments during the progression of the audition. The teachers at the audition are masters who are either current performers in the professional dance company, or faculty members who have previously been in a company. The conservatory degree is then four years of technique and repertory classes (all taught by master teachers who previously performed the work they are teaching) and performances. Within dance there is no individualized instruction, nor individualized curriculum. There is a previously defined curriculum of a minimum of one technique class per day (and usually many more) that is considered the best way to lead the students toward a performance career. Sometimes composition courses are included but they are also with master teachers who have achieved defined success in their field. In all these classes the focus is to achieve the success as defined by the master teacher, and in no instance, are any formal teaching qualifications substituted for this mastery of having been successful. This has become the model of the BFA program. Though general education requirements are included, they are often structured in a way that they further the performance development of the student. The conservatory model has focused mostly on modern dance, because classical ballet development usually leads to employment in a company by age 18 , so the college or university study is delayed. Modern dance also has a formal technique basis and is often growing closer to appearance of classical ballet. Often in the conservatory classical ballet technique classes are a requirement. These two dance forms, modern dance and classical ballet, are both western in their focus and in the development of the master mover, which resembles the closed system as discussed by Allsup. 


\section{Pedagogy}

The act of pedagogy is not the compartmentalization of one event from other events in the discipline. In its philosophical definition, pedagogy is about knowing people and about human interactions. Pedagogy begins with people and humanity so I see it as the first art form. This is the grounding to all knowledge and knowing in dance. With the separation of dance within academia into courses and degree specializations, one can say that dance education and dance pedagogy are the foundation from which all else emanates. This philosophical perspective is in alignment with the philosophical grounding of Remixing the Classroom.

Pedagogy is also synthesis area, rather than a separation. Within a traditional dance course there is pedagogical content knowledge and subject knowledge (Warburton 2008). Traditionally, dance academics are hired and valued for their subject knowledge. This is measurable as when one completes a degree, but it is also the very qualification that privileges a professional dancer over a dance academic. However, the often-overlooked pedagogical knowledge is the human side and from this perspective, the most significant side. Without engaging with and knowing others, we cannot transmit our "knowledge" or create new knowings in the world. However, the conservatory model values only the content knowledge side of this area.

Pedagogy is the series of actions that allow learners to acquire knowledge. The types of actions that are used for teaching are based in theories, rather than random ideas. Acquiring knowledge in movement is based in theories of motor learning (Clarkson and Skrinar 1988). Regardless of the type of knowledge, acquisition is a psychological process, so theories about pedagogy are psychological theories. Vygotsky developed the concept of the zone of proximal development, that we learn from those we are near who guide us (Phillips and Soltis 1998). Dewey (1938) wrote about the need for an active experience, in which the learner is engaged. With no experience, there is no learning. Jerome Bruner (1960) discussed scaffolding, or developing teaching processes in a building block fashion. From the work of Piaget (Phillips and Soltis 1998) is the theory of constructionism, that we construct our knowledge. There are many forms of critical pedagogy (hooks 1994; Shor, Giroux and others, see Fenstermacher and Soltis 1992) which enables the learner to question authority as it is the source of knowledge. The most well-known is "Pedagogy 
of the Oppressed" which is a widely-discussed theory developed by Paolo Freire (1970).

Pedagogy only becomes a series of actions when these theories are put into place guiding the interactions between student and teacher. Without these conscious actions, there is no pedagogy and then "teaching" becomes "giving knowledge" without creating the environment for the learner to acquire knowledge.

I define dance education as a way of understanding oneself and the world around us (2000). I still contrast it with training, which is a limited definition and one which I find many people truly mean, when using the term dance education. The definition of dance education that goes beyond training has a broader application, and does not reside in a specified technique, dance form, and certain viewpoint, that is, a closed form. It is also not limited to the gifted and talented. It is especially relevant within an ever-changing world when we need to question authority as the critical theorists guided us to do, so that the systems that we question are countered in thoughtful ways.

\section{Influences on Definition}

As stated earlier, dance entered academia in the 2oth Century not as a way to perfect performance, but as a way to know oneself from the scientific as well as philosophical perspective, in an integrated or holistic manner. This was H'Doubler's vision (Ross 2000). The influences of the time (from the mid-1920's) were the educational philosophies of John Dewey (1938) at Teachers College, Columbia University (New York City) that included child/student centered education as an aspect of progressive education as well as experiential education, and the health and physical education influences that focused on optimal movement functioning. Initially those influences were combined into a holistic version of dance. But by the later part of the 1900's the divisions became clear as higher education became a location for secure employment for many modern dancers of note. Two areas of contrast formed: the contrast of dance performance with dance education (Hagood 2000), and the contrast of modern dance with other dance forms (McPherson 2008). Within these conflicts, dance was also influenced by the other arts in higher education (music had a long- standing place in higher education and encouraged dance to align with it) and began to make the academic shift away from physical 
education into alignment with arts education (Hagood 2000). This alignment with the arts allowed those who came from the professional dance world to find a place of comfort in higher education, rather than an alignment with physical education. These issues still influence the definition of dance education today.

Simultaneously, the alignment with the arts that dance discovered within higher education also developed in the public education sector. This strengthened the voice of dance in academia and within public education providing dance the arts education advocacy that led to dance teacher certification and dance standards throughout the United States, in conjunction with other arts standards (Koff 1995). This advocacy was strengthened through the combined forces of four art forms (Dance, Art, Music and Theatre) leading not only to dance teacher certification in many states, but also to combined National Standards for the Arts (1994), which was led by MENC (Music Educators National Conference). Through the strength of the more established arts within education (music and visual art) dance was able to begin teacher certification within different states and the number of states has continued, with California adding dance teacher certification just this year. Unfortunately, this growth in the arts direction and definition resulted in a complete split from alignment with physical education (Hagood 2000). There were strengths and weaknesses to this split. Combined arts education advocacy gave dance a voice within a larger educational policy arena. However, splitting from physical education weakened the strength of research especially the deepening of our knowledge of the body and its optimal functioning. It also resulted in a split of dance forms, as western concert dance moved into alignment with the arts, but folk and social dance remained in its traditional home, physical education.

After splitting from physical education, most dance major curricula have maintained at least one anatomy course as a requirement. However, knowledge of the body and optimal functioning entails much more than one anatomy course. The argument against the full list of courses offered through physical education can be that the way in which the body is studied does not account for artistry. In response, the sub-discipline of dance medicine was created (see International Association for Dance Medicine \& Science, www.iadms.org) and several authors focused on that perspective (Fitt 1988; Clarkson and Skrinar 1988). But a dance medicine perspective focuses on injury care and prevention, rather than integrated optimal functioning. 
Perfecting performance has become a value in academia as the conservatory model has taken hold. This is evident in the large number of BFA and MFA programs that now proliferate in dance in the US. The MFA model developed in much the same way as the BFA, described earlier. This hierarchy of performance over other focal areas is parallel to what occurs in most disciplines, that those who excel in the performance are offered higher regard. It has also led to the master/apprentice mode, that is teacher directed and performance centered, as the dominant form of education (Allsup 2016) when considering the arts, rather than the education that is more student centered and full of open-ended possibility. The focus on performance is in opposition to the original values of dance in academia. More importantly, the master/apprentice model does not value the growth of the student as a holistic individual, but rather as a replication of the values of the master. The master/apprentice model can be a positive force in those spaces of specified, rarified instruction, but a space that Allsup challenges is not fulfilling the capacity of music education. This definition, of a "closed form" puts what is called "music education" really in the conservatory. I join him in adding dance education to his definition. Additionally, in this globalized world, who defines mastery? The nature of mastery creates hierarchy and, within dance, can lead to a hierarchy of technique, form, and culture. The forms present in this conservatory model in dance are the classical modern dance forms, and classical ballet. Excluded is folk and social dance, mentioned earlier. Excluded also are any forms that represent a nonwestern perspective. Additionally, those expert in any number of African dance forms, hip hop dance and other forms from non-western paradigms, where the body posture is not long and upright, and the line of the foot is not long and extended as a continuation of long leg line, are often considered not as skilled as those western dancers within US colleges and universities.

Allsup (2016) discusses the concept of form and studying form. Forms become systems; systems become history and therefore create a hierarchy, not to mention a lessening of, or dismissal of diversity. He does not advocate for totally dismissing or discarding forms or formalism, but rather, allowing for openness in knowing forms, then changing forms or moving on from forms. As he states: "A culture of closed forms is one of perfection, not uncertainty; submission, not play; elitism, not access; merit, not democracy; Law, not innovation" (55). There is a possibility of open forms, but it takes a different type of music education to develop the 
teacher who then creates space for possibility and allows an education that has a lack of knowing the outcome. In a sense, Allsup argues for fearlessness in the face of codified systems that all have forms (schools, assessment, certification, performance). Within this unknowing or uncertainty, we often see people retreat to spaces of safety and without challenge. But he also argues for having this open space because without challenge, without the risk-taking, growth will not occur. As dance has joined music in the combined arts education advocacy, dance education is also pulled into the same directions with regard to codified systems that all have forms (schools, assessment, certification, performance).

Through this argument and articulation of closed and open forms of education, and specifically music education, Allsup directly confronts some of the traditions of all these systems that, in some instance, lie outside the definition of music education. The master/apprentice model is certainly one of training and following a long-established system, but the notion of music education, as an opening of possibility and discovery, is not to be found within this training, according to Allsup (2016). This is much the same problem in dance education in that the conservatory model is a group version of the master/apprentice model, and it has become the pinnacle of dance training, but is sometimes confused with dance education. Dance education, in contrast, is a program that is much more aligned with the original curriculum at the University of Wisconsin created by H'Doubler (Ross 2000). The outcome is not to become a professional performer, but rather someone who is fully engaged with and aware of one's own body and expressive nature. It is someone who has knowledge of the formal systems, but is not limited to the formal systems alone, and is given the freedom to grow and develop in ways that are not prescribed. It is someone who is open to possibility and ideas and is able to move through one's own life as an engaged, expressive person. The dance educator is one who can guide students in this process through a co-created, questioning process. This is not the demanding teacher who wants "more, higher!" as an example. Guide is a purposeful word, and is one who works in open systems, as opposed to closed. Closed system teaching is directed, not guided, much as Vygotsky described (Phillips and Soltis 1998).

Within Allsup's definition, the entire systematic structure of public education, university teacher education, and learning the many aspects of music and its history perpetuate these closed systems and become their strength. It is much more 
difficult to work within the system, achieving standards, performing assessments, and contributing to the proscribed definitions that will enable all those who study to become employed, and challenge the same system simultaneously. The same is true within dance education, as described earlier. In order to challenge these entrenched systems, Allsup describes true outliers or renegades who operate in a "world" of their own creation, specifically Dapper Dan, an entertaining and enlightened haberdasher of Harlem. Yet, some of Allsup's basic philosophy resides in the work of John Dewey and Maxine Greene, giving hope that his ideas are not so daring, but have been in the discussions for many years. Dance Education also finds this same intersection with Allsup's work as the concepts perpetuated by Dewey and Greene have been the hallmarks of our definitions, including the definition of experience as an active and engaged encounter (Dewey 1938) and the concept of "wide-awakeness" so that we may experience and grow through our encounters in the world (Greene 1978). But within dance, closed system conservatories do not value the open system because it will not lead to the master performer model.

In considering hierarchies, Allsup challenges the western domination of music within music education, as I challenge the western domination of dance within dance education. Yes, there is beauty and elegance in those classics that we study, master, and pass on to our students. But if we remain within the study of those masters, not only are we not honoring the diversity of our students and our world, we are keeping the system closed. This is problematic as it leaves no room for growth, and for envisioning a better world. Within the traditional music education that Allsup discusses, there is room for art from a non-western canon, but it is often left on the periphery and labeled as "other." What, then, does this communicate to our students from backgrounds that are not the same as the western canon of music? Do they "see" themselves in this music? Are they led to believe that their own background is less worthy of study than the masters? The closed system is continued.

Allsup introduces each chapter and section with an insightful quote, often by Dewey or Greene. He begins the book with this quote from Greene:

To attend to music today is to find ourselves pushing back the boundaries of what we might have thought of as beautiful music. I still wonder at how unaware I was of so many frequencies; and I wonder how many remain unheard. (ix) 
Later in the book he returns to Dewey from more than one hundred years ago:

The thing needful is improvement of education, not simply by turning out teachers who can do better the things that are now necessary to do, but rather by changing the concept of what constitutes education. (36)

Allsup is not suggesting that we do something radical that has never been discussed. Rather he is thoughtfully asking us to go back and really look at our own practices and examine how we got here, and to honestly ask ourselves (as I imagine he is doing), "As a teacher, am I promoting growth? Do I allow myself to examine ideas and concepts for which there are no clear answers? Can I challenge my students to do the same?" This practice is what led me to examine the history of dance education, in order to comprehend what we are doing now when we say "dance education" and also to analyze if we are doing the best we can for our students.

The dividing point between being an excellent closed system teacher and an excellent open system teacher is this question: "Do we, in other words, teach a system or a child?” (Allsup 2016, 65). I have been pondering this very issue when working with dance educators. With Allsup's thoughtful inquiry into this question, he operates as a philosopher, peeling away the layers of meaning and interpretation to arrive at the core. He has done the difficult work for all of us in arts education, as I can now move forward and define myself as an arts educator who works for possibility and open-ended solutions for my own students, so that they can discover, grow and experience more than I ever have. This is true education, as I have defined for dance education, and this is the strength of Remixing the Classroom.

\section{About the Author}

Susan R. Koff is a Clinical Associate Professor and Director of the Dance Education Program at NYU/Steinhardt. Past positions include: the Kinesiology and Curriculum and Instruction faculties at Louisiana State University in Baton Rouge; coordinator of the Dance and Dance Education Program at Teachers College, Columbia University, a masters degree program preparing students for K-12 New York State Dance Certification; and faculty positions at the University of Denver, Pennsylvania State University and at the Jerusalem Rubin Academy of Music and Dance in Israel.

All of Dr. Koff's academic and service activities are in the area of Dance Education, both within the United States, and in the International arena. She currently serves as the Chair-Elect of the Board for Dance and the Child International (daCI). As a Fulbright Scholarship recipient, Dr. Koff assisted with the development of 
Dance Education Curriculum at the National School for Contemporary Dance, Copenhagen, Denmark. Publications are in the Journal of Dance Education, Research in Dance Education, and Childhood Education.

\section{References}

Allsup, Randall Everett. 2016. Remixing the classroom: Toward an open philosophy of music education. Bloomington: Indiana University Press.

Bruner, Jerome. 1960. The process of education. Cambridge, MA: Harvard University Press.

Clarkson, Priscilla M., and Margaret Skrinar, eds. 1988. Science of dance training. Champaign, IL: Human Kinetics Books.

Dewey, John. 1938. Experience and education. New York: Collier Books.

Fenstermacher, Gary D., and Jonas F. Soltis. 1992. Approaches to teaching. New York: Teachers College Press.

Fitt, Sally Sevey. 1988. Dance kinesiology. New York: Schirmer Books.

Freire, Paulo. 1970. Pedagogy of the oppressed. New York: Continuum Publishing Co.

Greene, Maxine. 1978. Landscapes of learning. New York: Teachers College Press.

Hagood, Thomas K. 2000. A history of dance in American higher education. Lewiston, NY: The Edwin Mellon Press.

Hagood, Thomas K., and Luke C. Kahlich, eds. 2013. Perspectives on contemporary dance history: Revisiting impulse, 1950-1970. Youngstown, NY: Cambria Press.

hooks, bell. 1994. Teaching to transgress. NY: Routledge.

Koff, Susan. 2000. Toward a definition of dance education. Childhood Education, 77 (1): 27-31.

Koff, Susan. 1995. Meaning making through the arts: Description of an urban high school's arts-based curriculum. EdD diss., Temple University.

McPherson, Elizabeth. 2008. The Contributions of Martha Hill to American dance and dance education, 1900-1995. Lewiston, NY: The Edwin Mellen Press. 
MENC. 1994. National standards for arts education. Reston, VA.

Phillips, D. C., and Jonas F. Soltis. 1998. Perspectives on learning. New York: Teachers College Press.

Ross, Janice. 2000. Moving lessons: Margaret H'Doubler and the beginning of dance in American education. Madison: The University of Wisconsin Press.

Warburton, Edward C. 2008. Beyond steps: The need for pedagogical knowledge in dance. Journal of Dance Education 8 (1): 7-12.

Koff, Susan R. 2017. Remixing the dance education classroom. Action, Criticism, and Theory for Music Education 16 (1): 66-78. doi:10.22176/act16.1.66 